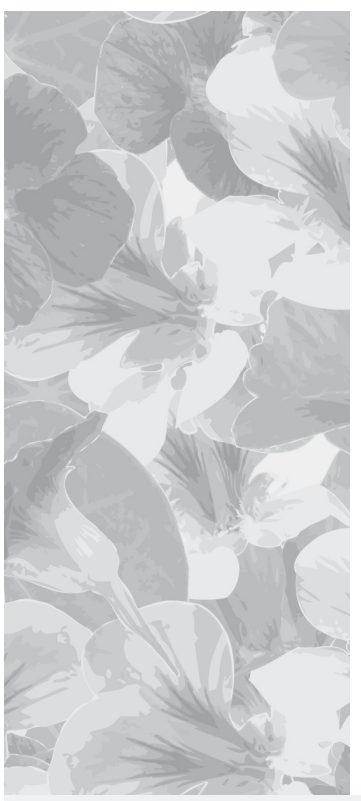

\title{
Motywacje, aspiracje edukacyjne i zawodowe oraz poziom kompetencji słuchaczy studiów magisterskich na kierunku kosmetologia Uniwersytetu Jagiellońskiego
}

\section{Motivation, educational and professional aspirations and level of competence of master students in cosmetology at the Jagiellonian University}

Olga Dębska-Ratuszniak, Danuta Plichta, Radosław Śpiewak

Zakład Dermatologii Doświadczalnej i Kosmetologii, Wydział Farmaceutyczny Uniwersytet Jagielloński Collegium Medicum, Kraków

Estetol Med Kosmetol 2012; 2(1): 28-32

DOI: http://dx.doi.org/10.14320/EMK.2012.006

\section{Streszczenie}

Kosmetologia jest nową dziedziną nauk o zdrowiu. W sektorze edukacyjnym nie ma dużego doświadczenia w zakresie kształcenia akademickiego na tym kierunku. W tworzeniu skutecznych programów nauczania cenna jest znajomość motywów i oczekiwań studentów. Cel: Celem badania byto poznanie motywacji, kompetencji, a także aspiracji edukacyjnych oraz zawodowych stuchaczy studiów magisterskich Wydziatu Farmaceutycznego Uniwersytetu Jagiellońskiego Collegium Medicum na kierunku kosmetologia. Materiał i metody: Przeprowadzono badania ankietowe wśród 132 studentek kierunku kosmetologia na Wydziale Farmaceutycznym Uniwersytetu Jagiellońskiego. Wyniki: Głównym motywem wyboru studiów kosmetologicznych było zainteresowanie dziedziną kosmetologii i pielęgnacją skóry (59\% uczestników badania). Decyzja o wyborze tego kierunku została podjęta samodzielnie przez $98 \%$ ankietowanych. Największy wpływ na wybór zawodu kosmetologa przez ankietowanych miała potrzeba samorealizacji, rozwijania siebie, swoich zdolności i zainteresowań (59\%). Większość studentek (71\%) w sytuacji ponownego wyboru kierunku studiów powtórnie zdecydowałaby się na kosmetologię. Najczęstszym motywem kontynuacji nauki na poziomie magisterskim była chęć podwyższenia kwalifikacji zawodowych (64\%) oraz zdobycia pełnego wyższego wykształcenia (54\%). Głównym powodem wyboru Uniwersytetu Jagiellońskiego jako miejsca studiowania byta renoma i prestiż tej uczelni. Na pytanie o wymarzone miejsce pracy po uzyskaniu tytułu magistra większość (54\%) wymieniła pracę w gabinecie dermatologicznym w charakterze współpracownika lekarza w zakresie pielęgnacji skóry. Najczęściej wskazywanym przez ankietowanych atutem pracy w zawodzie kosmetologa była możliwość podejmowania nowych wyzwań (54\%) oraz praca w przyjaznym otoczeniu (38\%), a wadą duża konkurencja na rynku pracy (75\%). Niemal połowa uczestników badania (45\%) wskazała że najbardziej obawia się w swojej przysztej pracy braku uregulowań prawnych zawodu. Wnioski: Decyzja studentów kosmetologii o wyborze kierunku studiów jest z reguty samodzielna i przemyślana. Studentom zależy na jakości kształcenia oraz poziomie nauczania.

Stowa kluczowe: studenci kosmetologii, motywacja, kompetencje, aspiracje, oczekiwania, studia magisterskie

\begin{abstract}
Cosmetology is a new branch of health sciences with relatively limited experience in academic teaching. In the process of shaping an effective curriculum, it is important to know the motivations and expectations of the students. Aim: To study the motivation, competence, as well as educational and professional aspirations of students of the Master of Science curriculum in cosmetology. Material and methods: A questionnaire survey of 132 master students of cosmetology in the Faculty of Pharmacy at the Jagiellonian University in Krakow, Poland. Results: The main motive for choosing this field of study was an interest in cosmetology and skin care (59\% of respondents). The decision to choose this field was taken autonomously by $98 \%$ of respondents; for most of them (59\%), the decisive factor was the need for self-realization, development of own skills and interests. The most common motive for continuing education at the master's level was to increase professional qualifications (64\%) and to receive a full university education (54\%). If they had to choose once again, most students ( $71 \%$ ) would still choose cosmetology as the field of their study. The main reason for choosing the Jagiellonian University as the place of education was the reputation and prestige of this institution. After graduation, they aspired to work in a dermatology clinic, as a physician's assistant in the field of skin care (54\%). The main advantages of working as a cosmetologist, in the opinions of the respondents were new challenges (54\%) and work in a friendly environment (38\%), the major disadvantage being the strong competition in the labour market (75\%). Almost a half of the students (45\%) were concerned about the lack of legal regulations in their future profession. Conclusions: Most students of cosmetology chose their field of study based on an independent decision and well-considered premises. The students appreciate the relevance of the quality of education.
\end{abstract}

Keywords: cosmetology students, master's study, motivation, competence, aspirations, expectations

Copyright @ 2012 the Authors (text) and Radosław Śpiewak (layout \& journal compilation). All rights reserved.

Kosmetologia jest nową dziedziną nauk o zdrowiu. Zaskakujące jest, że w słownikach, a nawet podręcznikach kosmetologii nie ma definicji tej dyscypliny. Według standardów kształcenia Ministerstwa Nauki i Szkolnictwa Wyższego absolwent studiów magister- skich na kierunku kosmetologia powinien być przygotowany nie tylko do ,wykonywania zabiegów kosmetycznych, pielęgnacyjnych i upiększających, ale także do ścisłej współpracy z lekarzem dermatologiem w zakresie pielęgnacji skóry zmienionej chorobowo, (...) oceny 
jakości surowców i preparatów kosmetycznych oraz współdziałania w procesie rejestracji kosmetyków oraz współpracy z firmami produkującymi preparaty kosmetyczne (pielęgnacyjne i profesjonalne)" [1]. Od ponad 50 lat postuluje się, aby zawód kosmetologa został uznany za zawód medyczny [2]. Zgodnie z rozporządzeniem Ministra Gospodarki i Pracy kosmetolog jest specjalistą ochrony zdrowia [3], jednak nie znajduje to odzwierciedlenia $\mathrm{w}$ innych regulacjach prawa. W sektorze edukacyjnym nie ma dużego doświadczenia w zakresie kształcenia akademickiego na kierunku kosmetologia. Jest to kierunek nowy, wzbudzający duże zainteresowanie, a chętnych na studia kosmetologiczne jest kilkakrotnie więcej niż dostępnych miejsc. W literaturze naukowej można znaleźć badania motywacji, aspiracji oraz kompetencji studentów niemal wszystkich kierunków paramedycznych [4-11], z wyjątkiem kosmetologii, co stało się motywem podjęcia niniejszych badań.

\section{Cel}

Celem pracy było poznanie motywacji, kompetencji, a także potrzeb edukacyjnych oraz aspiracji zawodowych słuchaczy studiów magisterskich na kierunku kosmetologia.

\section{Materiat i metody}

Badanie przeprowadzono na Wydziale Farmaceutycznym Collegium Medicum Uniwersytetu Jagiellońskiego w lutym i marcu 2012 roku. Objęło ono 138 słuchaczek studiów magisterskich I i II roku (kobiety w wieku od 23 do 43 lat, mediana 24 lata). Badanie zostało przeprowadzone za pomocą anonimowego kwestionariusza. W badaniu wykorzystano dwa warianty kwestionariuszy dla studentek I oraz II roku. Pytania miały formę zamkniętą (zaznaczenie wybranej odpowiedzi) lub formę otwartą (ankietowane udzielały odpowiedzi poprzez wpisanie w odpowiednim miejscu swojej opinii na dany temat). W pierwszej części kwestionariusza dla I oraz II roku studiów magisterskich ankietowane odpowiadały na pytania dotyczące motywów i potrzeb, jakimi kierowały się podczas dokonywania wyboru kierunku studiów i przyszłego zawodu kosmetologa, a także stopnia samodzielności w podejmowaniu tej decyzji. W drugiej części ankiety słuchaczki studiów I roku odpowiadały na pytania o miejsce odbywania studiów licencjackich (I stopnia) oraz kompetencje nabyte w ich trakcie. Natomiast studentki II roku odpowiadały w tej części na pytania o wiedzę oraz kompetencje uzyskane podczas edukacji na studiach magisterskich na Wydziale Farmaceutycznym CM UJ. Trzecia część ankiety dotyczyła motywów kontynuacji nauki oraz czynników mających wpływ na wybór uczelni kształcącej na studiach uzupełniających magisterskich. Respondentki mogły ponadto wyrazić swoją opinię na temat przydatności poszczególnych przedmiotów nauczania. Ostania część kwestionariusza służyła poznaniu przyszłych preferencji zawodowych studentek, a ponadto zalet i wad, a także obaw jakie niesie za sobą zawód kosmetologa. Częstość poszczególnych odpowiedzi podano jako wartości procentowe.

\section{Wyniki}

Po odrzuceniu 6 niekompletnych ankiet analizie poddano pozostałe 132. Badana grupa respondentek obejmowała zatem 132 osoby w wieku 23-43 lat (mediana 24 lata), w tym 74 studentki I roku (56\%) oraz 58 studentek II roku (44\%). Studentki kształcące się w trybie niestacjonarnym stanowiły 58\% (77 osób; wiek od 23 do 43 lat; mediana 24), zaś w trybie stacjonarnym 42\% (55 osób; wiek od 23 do 36 lat; mediana 24).

Motywy wyboru zawodu kosmetologa. Na pytanie o rodzaj potrzeb mających wpływ na podjęcie decyzji o wyborze zawodu kosmetologa największe znaczenie dla 78 osób (59\%) miała potrzeba samorealizacji, rozwijania siebie, swoich zdolności oraz własnych zainteresowań, a w dalszej kolejności uzyskania zawodu gwarantującego zaspokojenie podstawowych potrzeb (52 osoby; 39\%). Mało istotna okazała się natomiast potrzeba uznania ze strony otoczenia (44 osoby; 33\%), a najmniej ważna potrzeba przynależności do grupy zawodowej kosmetologów (54 osoby; 41\%). Motywy, jakimi kierowały się respondentki wybierając studia kosmetologiczne to przede wszystkim zainteresowanie dziedziną kosmetologii i pielęgnacją skóry (78 osób; 59\%), chęć posiadania zawodu pokrewnego z medycyną (47 osób; 36\%), uznanie zawodu kosmetologa za przyszłościowy, a dziedziny za prężnie rozwijającą się (42 osoby; 32\%), ,powołanie” (19 osób; 14\%), ,przypadek" (15 osób; 11\%), chęć pracy z ludźmi (12 osób; 9\%), oraz najrzadziej wskazywana chęć pomocy innym ludziom (11 osób; 8\%). Większość studentek kosmetologii (56 osób, 71\%) w sytuacji ponownego wyboru kierunku studiów nadal zdecydowałaby się studiować kosmetologię. Respondentki, które obecnie wybrałyby inny kierunek studiów (17 osób; 13\%), wskazywały na medycynę (5 osób), farmację i ekonomię (po 2 osoby), a pojedyncze osoby zdecydowałyby się na inne kierunki (np. iberystyka, inżynieria akustyczna, budownictwo).

Opinie studentek o programie studiów magisterskich. Spośród studentek II roku studiów magisterskich (58 osób), większość (43 osoby; 72\%) była zdania, że wiedza teoretyczna uzyskana podczas kształcenia na dwuletnich studiach magisterskich jest wystarczająca do podjęcia samodzielnej pracy. Oceniając uzyskane w trakcie studiów magisterskich praktyczne przygotowanie do zawodu, 24 respondentki (41\%) uznały nabyte umiejętności za niewystarczające do podjęcia samodzielnej pracy w zawodzie kosmetologa, natomiast tylko 17 (29\%) było zdania, że uzyskana wiedza praktyczna 
jest wystarczająca.

Samoocena kompetencji językowych. Wszystkie studentki twierdziły, że znają przynajmniej jeden język obcy, najczęściej wskazując na język angielski i niemiecki. Znajomość języka w stopniu umożliwiającym pracę z obcojęzycznym klientem zadeklarowało $76 \%$ (język angielski) oraz 53\% (język niemiecki), a umiejętność korzystania z obcojęzycznej literatury fachowej 34\% (język angielski) oraz 9\% (język niemiecki). Zdolność do podjęcia studiów w języku obcym deklarowało 9\% (język angielski) oraz 5\% (język niemiecki) ankietowanych.

Motywy podjęcia studiów magisterskich na Uniwersytecie Jagiellońskim. Najczęściej wskazywanym motywem kontynuacji nauki na poziomie magisterskim była chęć podwyższenia kwalifikacji zawodowych (84 osoby; 64\%) oraz zdobycie pełnego wyższego wykształcenia (71 osób; 54\%), a w następnej kolejności chęć dalszego rozwoju naukowego (59 osób; 45\%), potrzeba zwiększenia własnej konkurencyjności na rynku pracy (40 osób; 30\%), a ponadto namowa bliskich, rodziny lub przyjaciół (7 osób; 5\%). Dla zdecydowanej większości studentek (105 osób; 80\%) powodem wyboru Uniwersytetu Jagiellońskiego jako miejsca zdobywania tytułu magistra kosmetologii była renoma i prestiż uczelni. Obecność wykwalifikowanej kadry naukowej miała znaczenie dla 45 respondentek (34\%), natomiast 36 osób (27\%) wskazywało na czynniki pozamerytoryczne, takie jak atrakcyjność Krakowa (ryc. 1).

Rycina 1. Motywy wyboru Uniwersytetu Jagiellońskiego na studia magisterskie

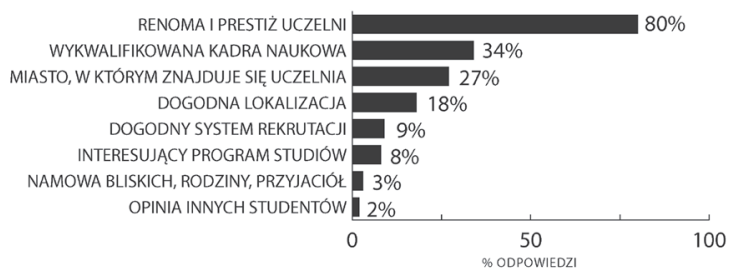

Oczekiwania wobec przyszłego zawodu. Najczęściej wskazywanym przez przyszłych magistrów kosmetologii preferowanym miejscem pracy był gabinet dermatologiczny, w którym absolwenci chcieliby współpracować z lekarzem w zakresie pielęgnacji skóry (71 osób; 54\%), a następnie gabinet kosmetyczny lub ośrodek odnowy biologicznej (66 osób; 50\%), w dalszej kolejności studentki wyrażały chęć pracy w charakterze nauczyciela zawodu w szkole lub na uczelni (50 osób; $38 \%$ ). Pracą w firmie produkującej kosmetyki przy opracowywaniu receptur nowych wyrobów, kontroli jakości i marketingu było zainteresowanych 38 studentek (29\%). Najmniej preferowana była praca w sieci dystrybucji kosmetyków oraz w charakterze sprzedawcy, konsultanta lub doradcy klienta (11 osób; 8\%). W chwili badania, w zawodzie kosmetologa pracowało 46 (35\%) respondentek. Spośród nich 18 (39\%) liczyło, że po studiach będą miały większą pewności zatrudnienia, a 16 (35\%) obiecywało sobie wyższe dochody jako główny efekt uzyskania tytułu magistra kosmetologii (ryc. 2).

Rycina 2. Spodziewane zmiany w sytuacji zawodowej po ukończeniu studiów w oczach studentów aktualnie pracujących w zawodzie kosmetologa $(n=46)$

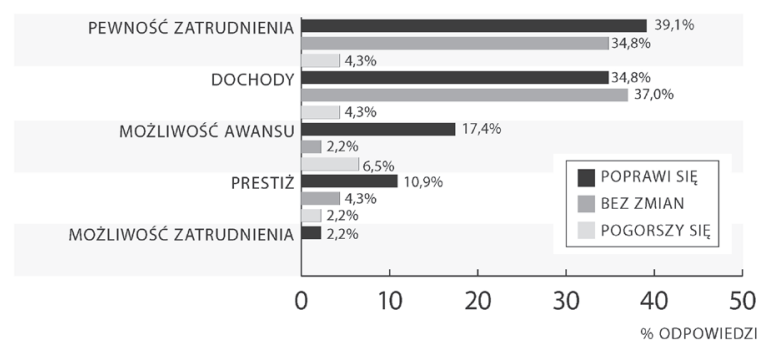

Ponad połowa ankietowanych (71 osób; 54\%) uważała, że głównym atutem pracy w zawodzie kosmetologa jest możliwość podejmowania nowych wyzwań, a w dalszej kolejności praca w przyjaznym otoczeniu (50 osób; 38\%), wysoki prestiż zawodowy (45 osób; 34\%), wysokie zarobki (24 osoby; 18\%), stabilne zatrudnienie (18 osób; 14\%) oraz nienormowany czas pracy (11 osób; 8\%). Dla większości respondentek (99 osób; 75\%) główną wadą zawodu kosmetologa jest duża konkurencja na rynku pracy, a ponadto nadmiar odpowiedzialności (34 osoby; 26\%), niskie zarobki i praca z niemiłymi klientami (po 32 osoby; 24\%) oraz nienormowany czas pracy (31 osób; 23\%). Niemal połowa studentek (59 osób; 45\%) obawia się problemów wynikających z braku jasno określonych ram prawnych zawodu kosmetologa. Niepokój budzi u nich również niedostatek własnych umiejętności (28 osób; 21\%), a także często zmieniające się przepisy prawne (17 osób; 13\%).

\section{Dyskusja}

Wyniki przedstawionych badań sugerują, że decyzja o wyborze kierunku studiów podejmowana jest przez studentki kosmetologii świadomie. Najczęściej wskazywanym (59\%) motywem podjęcia studiów kosmetologicznych jest zainteresowanie dziedziną, a zaledwie dla 8\% najważniejsza jest chęć niesienia pomocy ludziom. Odróżnia to studentki kosmetologii UJ od studentek pielęgniarstwa UMCS w Lublinie, wśród których chęć niesienia pomocy była istotna dla 79\% [4], a także od irańskich studentów medycyny i stomatologii, gdzie odsetek ten był jeszcze wyższy (88\%) [5]. Motyw niesienia pomocy był ważny dla $68 \%$ szczecińskich studentów medycyny i był wskazywany częściej niż zainteresowanie samą tematyką studiów (46\%) [6]. Można to podsumować, że studentki kosmetologii jako zbiorowość cechują się mniejszym od medyków poziomem altruizmu. Przypadek zadecydował o wyborze 
kierunku u 11\% ankietowanych studentek kosmetologii, identycznie jak wśród studentów farmacji badanych przez Bartkowiaka [7]. Zatem przypadek wydaje się odgrywać niewielką rolę w podejmowaniu decyzji dotyczącej kierunku kształcenia. W niniejszym badaniu ważnym motywem kontynuacji nauki na poziomie magisterskim była chęć podwyższenia kwalifikacji zawodowych $(64 \%)$ oraz zdobycia pełnego wyższego wykształcenia (54\%). Na ten sam powód wskazywało $39-84 \%$ studentek pielęgniarstwa [8,9]. Prestiż zawodu w obecnym badaniu był ważny dla co trzeciej studentki kosmetologii, co nie odróżnia tej grupy ani od polskich studentek pielęgniarstwa (46\%) [9], ani od nigeryjskich studentów stomatologii (36\%) [10]. Interesujące są natomiast różnice między studentkami kosmetologii i farmacji w zakresie oczekiwań dotyczących przyszłych dochodów. Tylko 14\% studentek kosmetologii uważa wysokie zarobki za najważniejszą zaletę pracy w zawodzie kosmetologa, co znacząco odróżnia je od studentów farmacji $(70 \%)$ [11].

Prawie połowa studentek kosmetologii (45\%) obawia się braku jasno określonych reguł działania w ich przyszłej pracy, co może skutkować niechęcią do podejmowania pracy w wyuczonym zawodzie. Obserwacja ta ilustruje, jak wielkim problemem jest w Polsce brak ustawy o zawodzie kosmetologa. Niska samoocena umiejętności praktycznych stanowi źródło obaw przed podjęciem pracy dla co piątej studentki kosmetologii. Z podobnych powodów rozczarowany podjętymi studiami jest co czwarty student farmacji [6]. Nasuwa się refleksja, że wielu studentów nie pojmuje idei studiów akademickich - zdają się oni uważać, że uniwersytet to taka bardziej prestiżowa szkoła zawodowa, myląc przy tym akademicki tytuł magistra $\mathrm{z}$ rzemieślniczym tytułem majstra. Z drugiej strony większość (80\%) studentek kosmetologii jako powód wyboru Uniwersytetu Jagiellońskiego wymienia renomę i prestiż uczelni oraz dostępność wykwalifikowanej kadry naukowej, co może świadczyć o tym, że dla większości studentek kosmetologii zdobycie akademickiego wykształcenia na wysokim poziomie jest cenną wartością.

\section{Wnioski}

1. Głównym motywem wyboru studiów kosmetologicznych jest zainteresowanie dziedziną kosmetologii i pielęgnacją skóry.

2. Wybierając zawód kosmetologa studentki kierują się potrzebą samorealizacji, rozwijania siebie i swoich zdolności oraz zainteresowań.

3. Studentki kosmetologii podejmują studia magisterskie, ponieważ chcą podwyższyć swoje kwalifikacje zawodowe i zdobyć pełne wyższe wykształcenie.

4. Dla studentek kosmetologii na Uniwersytecie Jagiellońskim największe znaczenie przy wyborze uczelni ma jej renoma i prestiż.
5. Najbardziej pożądanym zatrudnieniem po uzyskaniu tytułu magistra kosmetologii jest współpraca z lekarzem w gabinecie dermatologicznym w zakresie pielęgnacji skóry lub praca w gabinecie kosmetycznym i ośrodku odnowy biologicznej.

6. Za główną zaletę pracy w zawodzie kosmetologa studenci uważają możliwość podejmowania nowych wyzwań, natomiast za wadę - dużą konkurencję na rynku pracy.

7. Ponad połowa studentów kosmetologii obawia się w przyszłości problemów wynikających z braku jasno określonych ram prawnych zawodu kosmetologa.

\section{Piśmiennictwo}

1. Ministerstwo Nauki i Szkolnictwa Wyższego. Standardy kształcenia na kierunku Kosmetologia 2007. URL: http:// www.bip.nauka.gov.pl/_gAllery/63/88/6388/Zalacznik nr_4-kosmetologia.pdf (dokument elektroniczny, stan na dzień 25.03.2012).

2. Rudowska I: Kosmetyka lekarska. Wydawnictwo PZWL, Warszawa 1957: 3.

3. Rozporządzenie Ministra Gospodarki i Pracy z dnia 8 grudnia 2004 r. w sprawie klasyfikacji zawodów i specjalności dla potrzeb rynku pracy oraz zakresu jej stosowania. Dziennik Ustaw 2004; nr 99: poz. 1001.

4. Leoniuk K, Lemska M, Nowakowska H: Wyobrażenia studentów pielęgniarstwa na temat zawodu i pracy w systemie opieki zdrowotnej. Ann Univ Mariae CurieSkłodowska 2005; 60 suppl. 16 (3): 256-9.

5. Vahid Dastjerdi M, Mahdian M, Vahid Dastjerdi E, Namdari M: Study motives and career choices of Iranian medical and dental students. Acta Med Iran 2012; 50 (6): 417-24.

6. Gąsiorowski J, Radlińska I, Odej M, Kładna A: Postawy i motywacje studentów I roku Wydziału Lekarskiego PAM do nauki zawodu lekarza (część I). Zdrowie Publ 2008; 118 (2): 182-6.

7. Bartkowiak LE: Poglądy zawodowe absolwentów Wydziału Farmaceutycznego. Wiad Lek 2006; 59 (5-6): 303-10.

8. Salamon J: Wartości i cnoty etyczne pielęgniarki i ich znaczenie w pracy zawodowej. Onkol Pol 2005; 8 (3): 177-80.

9. Binkowska-Bury M, Marć M, Sobolewski M: Orientacja życiowa a czynniki motywujące młodzież do podejmowania kształcenia w zawodzie pielęgniarki w oparciu o badania studentów kierunku pielęgniarstwa Uniwersytetu Rzeszowskiego. Przegl Med Uniw Rzeszow 2005; 2: 149-55.

10. Orenuga OO, da Costa OO: Characteristics and study motivation of clinical dental students in Nigerian universities. Int Dental Education 2006; 70 (9): 996-1003.

11. Kurczewska U, Jasińska M, Orszulak-Michalak D: Motywy wyboru studiów farmaceutycznych na przykładzie Uniwersytetu Medycznego w Łodzi. Farmacja Współczesna 2008; 1: 64-8. 


\section{Finansowanie i konflikt interesów}

Niniejszy artykuł powstał na bazie pracy magisterskiej Olgi Dębskiej-Ratuszniak (promotor: Radosław Śpiewak) obronionej na Wydziale Farmaceutycznym UJ. Przedstawione badania i przygotowania niniejszej publikacji zostało $\mathrm{w}$ całości sfinansowane $\mathrm{z}$ własnych środków autorów. Autorzy deklarują niewystępowanie konfliktu interesów w odniesieniu do treści zawartych w niniejszej pracy.

\section{Adres do korespondencji}

prof. UJ dr hab. med. Radosław Śpiewak Zakład Dermatologii Doświadczalnej i Kosmetologii Wydział Farmaceutyczny UJ ul. Medyczna 9, 30-688 Kraków Tel.: 1262058 30, Fax: 126205645

E-mail: spiewak.eu@gmail.com

Data złożenia: 13.05.2012

Data akceptacji: 23.06.2012

Data aktualizacji: 30.11 .2012

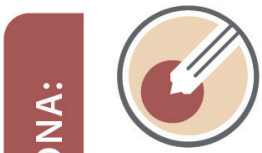 \\ alergologia.org \\ PORTAL LEKARZY ALERGOLOGÓW}

\section{Ponad 20 tysięcy wizyt miesięcznie!}

Służy alergologom od 2005 roku, zdobywając uznanie i zaufanie.

Dostarcza rzetelnych i aktualnych informacji potrzebnych w codziennej praktyce, rozwoju zawodowym i naukowym.

Ma wszystko, czego potrzebujesz:

- kalendarz konferencji i szkoleń - profile specjalistów alergologów - wykaz ośrodków alergologicznych - autorskie blogi specjalistów alergologów

- Alergoforum i pytania do eksperta - archiwum materiałów konferencyjnych - omówienia ważnych publikacji krajowych i światowych - informacje o organizacjach alergologicznych - przegląd literatury alergologicznej

. i wiele więcej...

\section{TWOJE PROFESJONALNE MIEJSCE W SIECI}

Przedstaw się z najlepszej strony: załóż profil specjalisty alergologa... Badź na bieżąco: śledź to, co w naszym środowisku naprawdę ważne...

Daj się poznać: dziel się przemyśleniami i doświadczeniem na swoim autorskim blogu... 